\title{
DEPOIMENTO: EdUARDO VIEIRA MARTINS, UM HOMEM ENTRE LIVROS
}

http://dx.doi.org/10.11606/issn.2237-1184.v0i34p30-31

Mirhiane Mendes de Abreu

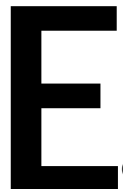

duardo dedicou sua vida aos estudos literários. Hoje, visitar suas notas, seus cadernos, suas aulas é tornar presente um homem que escolheu viver entre livros. No momento em que percorro nossas estantes para escolher entre cadernos, programas e notas algo que possa exprimir a dedicação do Professor Eduardo ao magistério, eu me deparo com o modo pelo qual ele caminhou e escolheu construir uma carreira sólida e organicamente interligada. Nessa ocasião de homenagem e saudade, nossos filhos e eu revivemos não apenas notas soltas, mas um projeto particular de alguém que associou a pesquisa à docência, e ambas, à vida.

Nenhuma apresentação às aulas de Eduardo estaria completa se não levasse em conta o paradigma da disciplina e da concepção metodológica da pesquisa. Fosse lá nos idos do mestrado, quando desenvolveu sua dissertação sobre $O$ sertanejo, de José de Alencar; fosse a pesquisa de doutorado que resultou na publicação do livro A fonte subterrânea; fosse na produção de sua tese de livredocência, ainda inédita, Os lugares do sertão e outros estudos, acompanhei de perto a produção de uma obra enraizada na retidão intelectual, no rigor dos conceitos e na profundidade das análises. Estes também foram os valores nos quais ele buscou fixar o desenvolvimento de seus cursos como professor de literatura brasileira da Universidade Estadual de Londrina, na Universidade Paris 8 e, desde 2004, no Departamento de Teoria Literária e Literatura Comparada na Universidade de São Paulo.

Por isso, seria limitado apenas reproduzir uma de suas aulas sem sublinhar seu método, porque Eduardo estabeleceu, para cada uma delas, um trabalho de sólida investigação acadêmica que enforma sua perspectiva crítica cultivada ao longo dos anos. A docência significava para ele uma atividade de análise teoricamente bem conduzida, o que lhe permitiu construir um programa de ensino não apenas descritivo, mas erigido por critérios teóricos concatenados à

I Universidade Federal de São Paulo, Guarulhos, São Paulo, Brasil. 
coerência interna do texto apreciado. Portanto, quando se trata de conhecer as aulas de Eduardo, dispondo-as da maneira como ele as ordenou, é importante considerar os sentidos da sua crítica literária: o histórico, que se constituiu numa investigação de obras do século XIX, expondo-as sob o ângulo das práticas letradas daquele tempo; o teórico, a partir do qual empreendeu uma sistematização da imagem do sertão na literatura brasileira, compreendendo-a pelos estudos teóricos da paisagem; e, finalmente, o crítico, um exame das obras, percebendo nelas a dimensão topográfica e universal. O corpo central de suas aulas não se distinguia da dimensão dos ensaios e livros que publicou e nelas repousa o timbre didático e sensível para ensinar aos alunos a interpretação de obras a partir da sistematização teórico-crítica.

As notas e a aula que se seguem reproduzidas dão mostras de que o crítico e o professor enfeixam a mesma pessoa de vida plena, reta e amável que foi Eduardo. Escolhi um fichamento anotado e uma aula introdutória à disciplina Introdução aos Estudos Literários I (IEL I), por considerá-los exemplares da sua atividade crítica e docente e porque neles se encontram igualmente a habilidade de análise, a clareza da exposição das ideias e as preocupações estilísticas. Resumidamente aqui exposta, a carreira de Eduardo foi sólida e coesa. Ele nos deixou precocemente, mas suas obras permanecerão.

Mirhiane Mendes de Abreu é professora de Literatura Brasileira da Universidade Federal de São Paulo (Unifesp). Graduada em Letras pela Universidade Federal Fluminense (UFF), é mestre e doutora em Teoria e História Literária pela Universidade Estadual de Campinas (Unicamp), onde também realizou o pós-doutorado. Realizou estágio de investigação em Paris 3 (Sorbonne Nouvelle). É Colaboradora Externa do Instituto de Estudos de Literatura e Tradição da Universidade Nova de Lisboa (IELT/UNL) e Pesquisadora Colaboradora do Instituto de Estudos Brasileiros (IEB/USP), desenvolvendo pesquisa sobre a imagem de Portugal em Mário de Andrade. Contato: mirhiane.m.abreu@gmail.com

ORCiD: https://orcid.org/0000-0003-0913-5078 